\title{
RESPON PERTUMBUHAN JABON (Anthocephalus cadamba (Roxb.) Miq.) TERHADAP LUBANG RESAPAN BIOPORI PADA LAHAN BEKAS TAMBANG
}

\author{
Jabon (Anthocephalus cadamba (Roxb.) Miq.) Growth Response in Application of Biopori \\ Hole Infiltration on Postmining Area
}

Irdika Mansur $^{1^{*}}$ dan Rian Prakosa Wijaya ${ }^{1}$

(Diterima Februari 2018/Disetujui September 2019)

\begin{abstract}
Growth of jabon (Anthocephalus cadamba) on postmining area is not optimal due to the acidic soil and very low nutrients content. Liming and Hole Infiltration of Biopori was an effort to improve Jabon growth. Lime can neutralize acid and Hole Infiltration of Biopori (LRB) can expand the ground to absorb water during the rain. In addition to the litter in the LRB able to improve soil nutrients. The purpose of this research was to improve jabon growth through LRB and to know the best of the LCC (Legume Cover Crops) plant leaves, leaf of Acacia mangium, or organic kitchen waste for LRB. LCC Leaf litter was reached best results based on the diameter due to having rata-rata highest and significantly different part with treatment $P 2$ (LRB containing acacia leaf) and PO (control). Kitchen waste $(P 3)$ is litter stuffing in the best LRB based on parameters high because significantly different with control $(P 0)$ and has the highest average.
\end{abstract}

Key words: hole infiltration of biopori, jabon, LCC leaf, liming, kitchen waste

\section{PENDAHULUAN}

Indonesia merupakan negara dengan sumber daya alam (SDA) yang sangat melimpah. Salah satu SDA yang diproduksi Indonesia dan sebagai komoditi ekspor yang memberikan sumbangan besar kepada devisa negara yaitu dari sektor tambang batubara. Indonesia merupakan salah satu penghasil batu bara terbesar di dunia dengan produksi 391 juta ton pada tahun 2013 (ESDM 2013). Lokasi pertambangan yang banyak berada pada kawasan hutan menuntut para pemegang izin pertambangan untuk mengembalikan lahan sesuai dengan aturan dan peruntukannya.

Reklamasi menjadi penting dilakukan dengan besarnya lahan yang terdegradasi dan terdeforestasi. Oleh karena itu pemerintah mengatur tentang reklamasi lahan dalam UU No.4 tahun 2009 pasal 26 reklamasi adalah kegiatan yang dilakukan sepanjang tahapan usaha pertambangan untuk menata, memulihkan, dan memperbaiki kualitas lingkungan dan ekosistem agar dapat berfungsi kembali sesuai peruntukannya.

Sementara dalam UU No.41 tahun 1999 tentang Kehutanan pada pasal 44 ayat 3 menyebutkan reklamasi hutan sebagaimana dimaksud dalam Pasal 21 huruf c, meliputi usaha untuk memperbaiki atau memulihkan kembali lahan dan vegetasi hutan yang rusak agar dapat berfungsi secara optimal sesuai dengan peruntukannya.

Kesadaran yang tinggi terhadap upaya mengembalikan keadaan alam daerah bekas

\footnotetext{
${ }^{1}$ Departemen Silvikultur, Fakultas Kehutanan Institut Pertanian Bogor

* Penulis koresponden:

E-mail: irdikam@gmail.com
}

penambangan sangat diperlukan untuk tetap menjaga keseimbangan ekosistem hutan yang telah habis ditebang. PT Tunas Inti Abadi merupakan perusahaan pertambangan batubara yang memiliki komitmen dalam mengembalikan keadaan alam mendekati keadaan sebelumnya. Hal ini dapat dilihat dari keberhasilannya mendapatkan sertifikat pengelolaan lingkungan berdasarkan Standar ISO 14001:2004 pada akhir tahun 2013. Selain itu perusahaan dalam menjalankan kegiatan operasionalnya, semua karyawan berpedoman pada 4 komitmen salah satunya komitmen yang tinggi dalam upaya mengembalikan ekosistem hutan yang hilang dalam proses eksflorasi.

Hutan memiliki fungsi konservasi yang dapat melindungi segala macam plasma nutfah yang ada di dalamnya baik flora maupun fauna, fungsi lindung sebagai fungsi hidrologi yang mengatur sistem aliran air yang berguna dalam peyediaan air bersih untuk kehidupan manusia, bahkan fungsi produksi yang dapat memberikan keuntungan ekonomi tinggi bila dikelola dengan bijaksana dari hasil hutan kayu maupun hasil hutan non-kayunya. Selain itu fungsi hutan yang marak diperbincangkan yaitu potensi hutan yang dapat menyerap karbon yang merupakan penyebab utama dari Green House Effect. Dengan fungsi yang luar biasa tersebut tidak dapat dipungkiri bahwa kehidupan manusia sangat tergantung dengan adanya hutan hujan tropis yang sebagian besar berada di Indonesia yang memiliki luas hutan 139 juta ha pada tahun 2009 (Kemenhut 2009).

Lahan bekas tambang batubara, khususnya di PT. Tunas Inti Abadi memiliki lahan dengan tingkat keasaman yang tinggi ditunjukkan dengan pertumbuhan pohon jabon (Anthocephallus cadamba) yang kerdil dan 
gemuk. Upaya untuk meningkatkan pertumbuhan jabon di area ini sangat perlu dilakukan. Pengapuran merupakan upaya dalam mengatasi keasaman tanah yang tinggi ditambah dengan pemberian Lubang Resapan Biopori (LRB) untuk menambah bahan organik bagi tumbuhan sebagai pasokan makanan.

\section{METODE PENELITIAN}

\section{Waktu dan Lokasi Penelitian}

Penelitian ini dilaksanakan pada tanggal 6 Maret 2014 sampai 11 Mei 2014 pada lokasi in pit dam (IPD) 2 pada lahan bekas tambang PT. Tunas Inti Abadi Kabupaten Tanah Bumbu, Propinsi Kalimantan Selatan.

\section{Alat dan Bahan}

Alat-alat yang digunakan adalah bor tanah dengan diameter $10 \mathrm{~cm}$, meteran $50 \mathrm{~m}$, caliper digital, tally sheet, timbangan $2 \mathrm{~kg}$, penggaris $100 \mathrm{~cm}$, kantong plastik, karung, dan alat tulis. Bahan yang digunakan dalam penelitian ini adalah contoh tanah dari lahan yang ditanami Jabon, kapur $\left(\mathrm{CaCO}_{3}\right)$, daun Acacia mangium, daun tumbuhan LCC, sampah organik dari dapur PT TIA (sampah dapur), tanaman Jabon berumur 1 tahun yang telah berada di lokasi penelitian.

\section{Prosedur Penelitian}

\section{Persiapan}

Persiapan penelitian dimulai dengan menyiapkan alat-alat yang digunakan selama penelitian, menyiapkan bahan-bahan isian LRB yaitu daun tumbuhan LCC, daun akasia, dan sampah dapur dikumpulkan dalam karung dengan berat masing-masing jenis $16 \mathrm{~kg}$. Selain itu juga disiapkan kapur yang telah ditimbang seberat 500 gram sebanyak 30 paket.

\section{Pengambilan Sampel Tanah dan Analisis Tanah}

Pengambilan sampel tanah dilakukan pada minggu ke-7 dengan mengambil tanah dari 9 titik yang mewakili

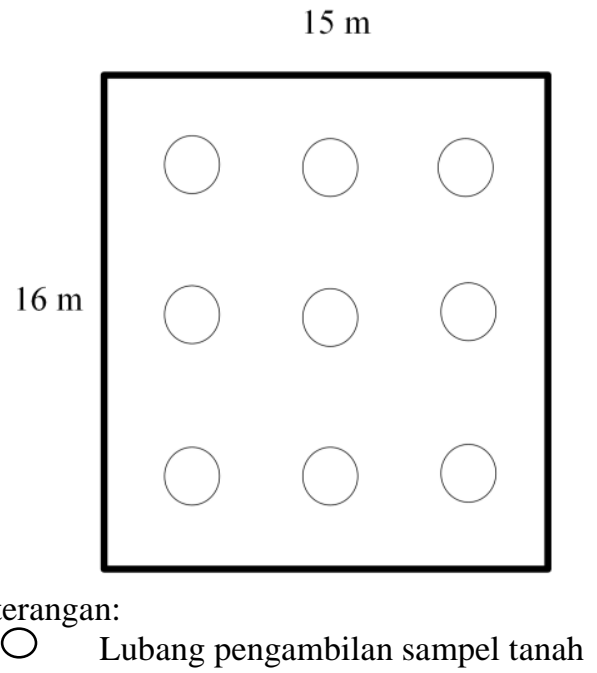

Gambar 1 Layout pengambilan sampel tanah pada lahan penelitian lahan yang diteliti (Gambar 1). Terdapat 2 jenis sampel tanah yang diambil dari lapisan tanah atas setebal $10 \mathrm{~cm}$ dan lapisan tanah bawah diambil dari kedalaman $10 \mathrm{~cm}$ $-20 \mathrm{~cm}$.

Setiap sampel tersebut dicampur tiap jenisnya dan di ambil $1 \mathrm{~kg}$ tanah untuk kemudian di analisis di laboratorium SEAMEO BIOTROP. Penyampuran tanah menggunakan metode komposit sehingga didapat tanah yang mewakili sample penelitian. Tanah yang tersisa 1 $\mathrm{kg}$ dari setiap sampelnya ini kemudian disimpan pada tempat yang sejuk sehingga dapat mencegah organisme lain untuk berkembang. Lama pengujian tanah di laboratorium adalah 34 hari.

\section{Pembuatan Lubang Resapan Biopori}

Pembuatan Lubang Resapan Biopori dilakukan dengan menggunakan bor tanah manual yang memiliki diameter $10 \mathrm{~cm}$. Tanah dilubangi menggunakan bor hingga mencapai kedalaman $40 \mathrm{~cm}$. Setiap pohon memiliki 2 buah lubang yang diisi daun Acacia mangium atau daun LCC atau sampah dapur . Berat setiap isian LRB yaitu $1 \mathrm{~kg} / \mathrm{lubang}$. Bahan isian pada 2 buah LRB di setiap pohon memiliki jenis yang sama.

\section{Pengapuran Lahan}

Pengapuran dilakukan dengan cara membersihkan rumput dan menggemburkan tanah di sekitar pohon seluas $1 \mathrm{~m}^{2}$ dan kedalaman $10 \mathrm{~cm}$ kemudian mencampurnya dengan kapur (CaCO3). Dosis kapur yang digunakan adalah sama pada setiap pohon yaitu 500 gram/pohon.

\section{Pengukuran}

Pengukuran dilakukan selama 8 minggu berturutturut pada setiap minggunya. Pengukuran diameter menggunakan alat jangka sorong (caliper) pada setiap pohon di ruas pertama batang pohon. Sementara pengukuran tinggi pohon menggunakan meteran yang dibantu dengan tongkat kayu. Pengukuran tinggi dilakukan dengan mengukur panjang pohon dari pangkal batang hingga tajuk yang paling tinggi. Selain itu juga dilakukan penghitungan jumlah cabang dan daun.

\section{Pemeliharaan}

Pemeliharaan yang dilakukan adalah pengendalian hama dan penyakit dengan membuang hama yang menyerang pohon. Pemeliharaan ini dilakukan selama 8 minggu.

\section{Rancangan Penelitian}

Metode pengolahan data yang dilakukan adalah dengan menggunakan uji $\mathrm{T}$ dengan bantuan software SPSS 21. Terdapat beberapa variabel yang diukur pada penelitian ini. Variabel tersebut adalah pertumbuhan diameter, pertumbuhan tinggi, pertambahan jumlah cabang dan pertambahan jumlah daun pada setiap pohon jabon. Setiap variabel ini diukur pada setiap minggu. Data yang didapat selanjutnya dianalisis untuk diketahui apakah antar perlakuan memberikan perbedaan sebaran nilai dengan menggunakan taraf kepercayaan $95 \%$.

Rancangan yang digunakan dalam penelitian ini adalah metode Independent Sample T-Test dengan 6 kali 
ulangan pada kontrol dan 8 kali ulangan pada perlakuan 1,2, dan 3. Faktor P adalah faktor jenis bahan isian LRB dengan 4 taraf.

Perlakuan yang diberikan adalah:

Perlakuan, P0 : 500 gr/pohon kapur CaCO3 tanpa ada LRB (kontrol)

P1 : 500 gr/pohon kapur CaCO3dengan LRB berisi daun Acacia mangium

P2 : 500 gr/pohon kapur $\mathrm{CaCO} 3$ dengan LRB berisi daun LCC (Legume Cover Crops)

P3 : 500 gr/pohon kapur CaCO3dengan LRB berisi sampah Organik

Hipotesis yang digunakan adalah

H0: Tidak terdapat perbedaan nilai yang nyata dalam kombinasi antar perlakuan.

H1: Terdapat perbedaan nilai yang nyata dalam kombinasi antar perlakuan.

\section{HASIL DAN PEMBAHASAN}

\section{Hasil Pengamatan}

Terdapat beberapa parameter yang diukur pada penelitian ini, yaitu pertumbuhan diameter, tinggi, pertambahan jumlah cabang dan jumlah daun pada setiap pohon Jabon. Tabel 1 menjelaskan bahwa parameter yang menunjukkan perbedaan nyata adalah tinggi dan diameter jabon sedangkan jumlah cabang dan jumlah daun tidak berbeda nyata.

\section{Pengukuran pertumbuhan diameter}

Pada Gambar 2 perbedaan pertumbuhan cukup mencolok ditunjukkan perlakuan P1 yang

Tabel 1 Rekapitulasi hasil sidik ragam setiap parameter

\begin{tabular}{clc}
\hline No & \multicolumn{1}{c}{ Parameter } & Jenis Isian LRB \\
\hline 1 & Diameter & $*$ \\
2 & Tinggi & $*$ \\
3 & Jumlah daun & tn \\
4 & Jumlah cabang & tn \\
\hline
\end{tabular}

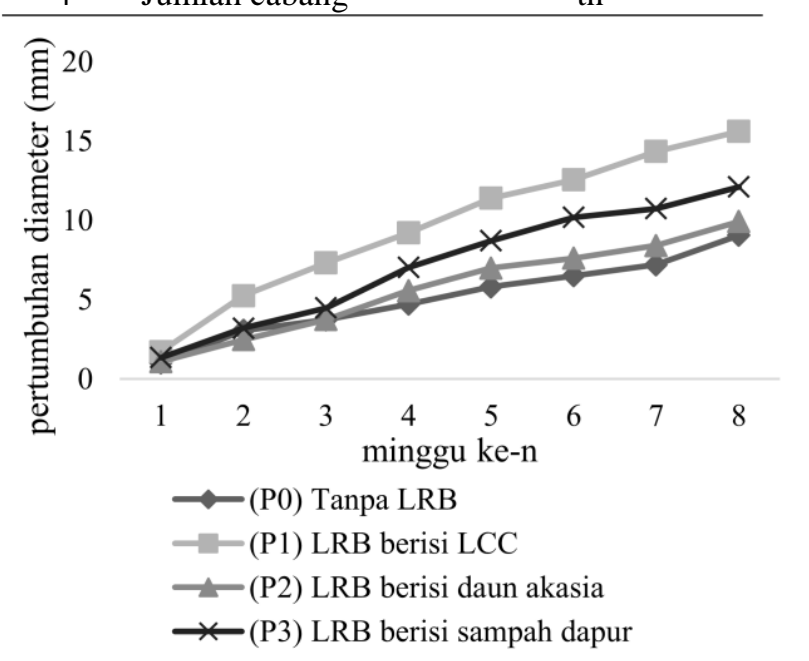

Gambar 2 Grafik pertumbuhan dimeter jabon pertumbuhannya dari minggu kedua hingga minggu kedelapan terus meningkat menjauhi grafik pertumbuhan diameter dari 3 perlakuan yang lain. Pada perlakuan P0, P2 dan P3 pertumbuhan diameter dari minggu pertama hingga minggu ke-3 memiliki tingkat pertumbuhan yang hampir sama atau hanya memiliki perbedaan angka yang tidak terlalu besar. Minggu keempat hingga minggu terakhir menunjukkan bahwa pertumbuhan ketiga perlakuan tersebut mulai menunjukkan perbedaan.

Gambar 3 merupakan hasil Uji Duncan pertumbuhan jabon selama 8 minggu pada setiap perlakuan. Jabon dengan perlakuan P1 memiliki pertumbuhan yang paling tinggi, sedangkan perlakuan P0 memberikan pertumbuhan yang paling rendah. Perbedaan pengaruh perlakuan yang diberikan ditunjukkan dengan huruf yang ada di sebelah nilai rataan pada setiap perlakuan. Huruf yang berbeda menunjukkan perbedaan nyata dan sebaliknya.

Jabon dengan perlakuan LRB berisi LCC memiliki pengaruh yang nyata apabila dibandingkan dengan perlakuan LRB berisi daun akasia dan tanpa LRB, namun tidak berpengaruh nyata dengan LRB berisi sampah dapur. Perlakuan LRB berisi daun akasia dan tanpa LRB memiliki perbedaan yang tidak nyata. Sama halnya dengan perlakuan LRB berisi LCC, daun akasia, dan sampah dapur memiliki perbedaan yang tidak nyata.

\section{Pengukuran pertumbuhan tinggi}

Gambar 4 menunjukkan adanya perubahan pola peningkatan pertumbuhan. Pada minggu pertama hingga minggu keempat menunjukkan bahwa pertumbuhan terjadi namun tidak terlalu tinggi. Sementara pertumbuhan tinggi jabon pada minggu keempat hingga minggu kedelapan memiliki peningkatan pertumbuhan yang lebih tinggi, pada perlakuan P1, P2, dan P3. Sementara pada perlakuan $\mathrm{P} 0$ peningkatan pertumbuhan tinggi cenderung lebih konstan dan tidak terlihat perbedaan pola.

Dari hasil pengumpulan data menunjukkan bahwa pada variabel tinggi, LRB berisi sampah dapur memberikan pertumbuhan yang paling tinggi. Hal ini berbeda dengan variabel diameter. Sedangkan kontrol

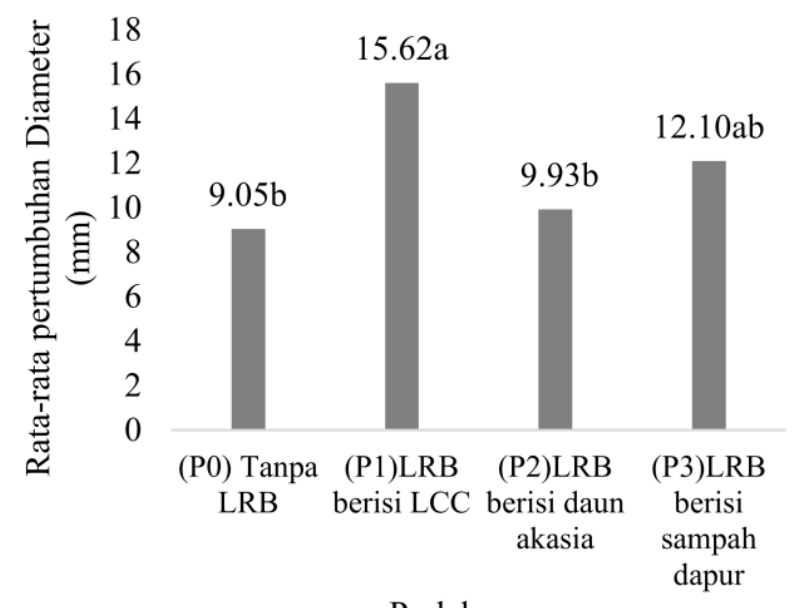

Perlakuan

Gambar 3 Hasil Uji Duncan pertumbuhan diameter pohon 
tetap menjadi perlakuan yang memberikan pengaruh paling rendah bersama LRB berisi daun akasia yang sedikit lebih tinggi.

Analisis data dengan Uji Duncan (gambar 5) menunjukkan bahwa hanya ada 2 interaksi yang memberikan perbedaan nilai. Berdasarkan gambar tersebut hanya perlakuan tanpa LRB dan LRB berisi sampah dapur yang memberikan perbedaan yang nyata. Sementara antar perlakuan yang lain tidak memberikan perbedaan yang nyata. LRB berisi LCC memiliki rataan yang lebih tinggi daripada LRB berisi daun.

\section{Pengukuran Jumlah Daun}

Tabel 2 menunjukkan bahwa penambahan jumlah daun yang dihasilkan jabon selama 8 minggu memiliki peningkatan yang relatif sama. Hal yang sama juga ditunjukkan dari hasil analisis statistik berdasarkan data pertumbuhan jumlah daun jabon yang menunjukkan bahwa $\mathrm{F}$ hitung lebih kecil daripada $\mathrm{F}$ Tabel sehingga tidak ada satupun perlakuan yang memberikan pengaruh nyata terhadap parameter jumlah cabang.

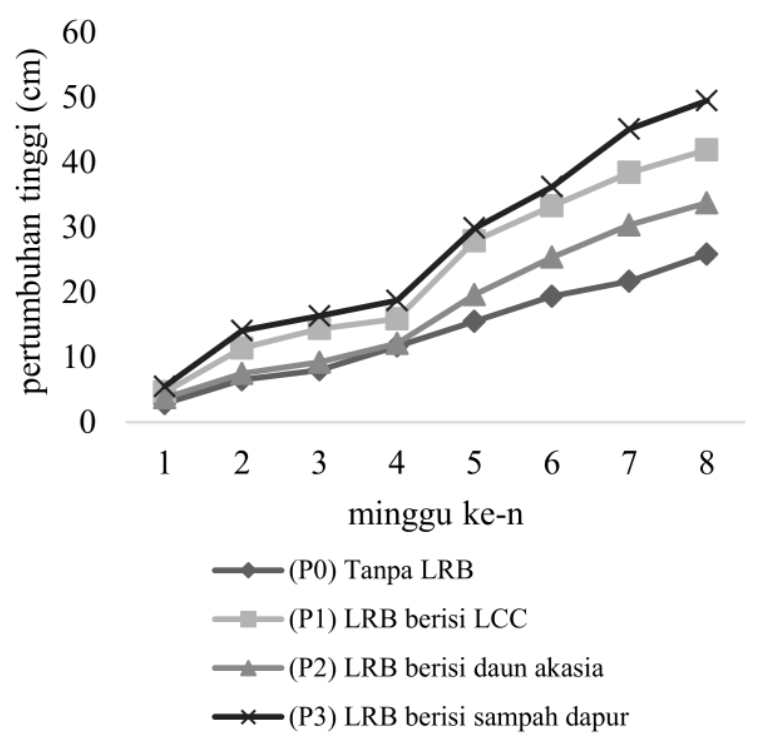

Gambar 4 Grafik pertumbuhan tinggi jabon

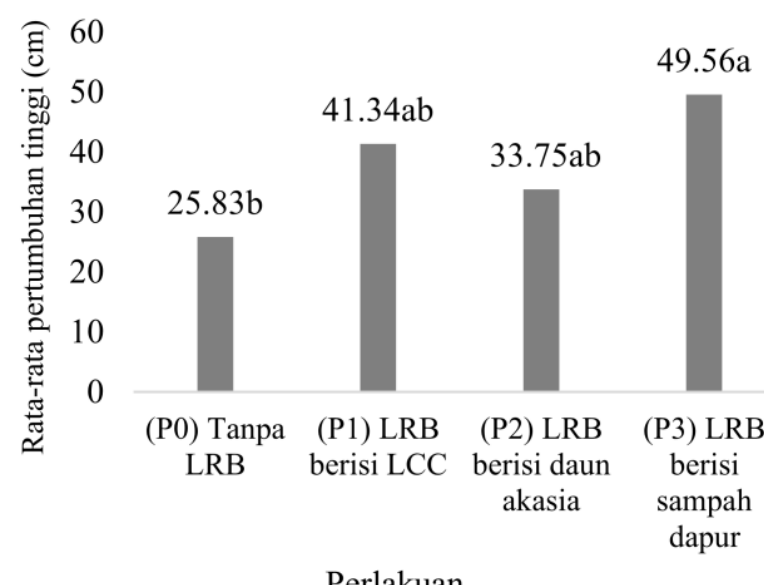

Gambar 5 Hasil Uji Duncan pertumbuhan tinggi pohon

\section{Pengukuran Jumlah Cabang}

Dari hasil yang didapat, jumlah cabang yang dihasilkan tidak banyak bahkan hanya tumbuh rata-rata 1 cabang di setiap minggunya. Pertumbuhan cabang yang hanya 1 buah ini ditunjukkan oleh semua perlakuan bahkan hampir serentak di minggu ke-5 kecuali pada kontrol yang telah tumbuh dari minggu ke3. Pertumbuhan cabang jabon ini dapat dilihat pada Tabel 3.

\section{Hasil Analisis Tanah}

Hasil analisis tanah terhadap 2 sampel tanah yang diambil dari lapisan tanah atas setebal $10 \mathrm{~cm}$ dan lapisan tanah bawah dari kedalaman $10 \mathrm{~cm}-20 \mathrm{~cm}$. Berdasarkan Tabel 4 menunjukkan bahwa tanah tersebut pada umumnya memiliki tingkat kesuburan yang hanya pada rentang rendah atau sangat rendah, hanya ada 1 nilai pengujian yang memiliki nilai sedang yaitu pada jumlah $\mathrm{Mg}$.

\section{Pembahasan}

Tabel 2 Penambahan jumlah daun jabon

\begin{tabular}{ccccccccc}
\hline Perlakuan & \multicolumn{1}{c}{ Pertambahan cabang pada minggu ke- } \\
\cline { 2 - 8 } & 1 & 2 & 3 & 4 & 5 & 6 & 7 & 8 \\
\hline P0 & 0 & 0 & 1 & 1 & 1 & 1 & 1 & 1 \\
P1 & 0 & 0 & 0 & 0 & 1 & 1 & 1 & 1 \\
P2 & 0 & 0 & 0 & 0 & 1 & 1 & 1 & 1 \\
P3 & 0 & 0 & 0 & 0 & 1 & 1 & 1 & 1 \\
\hline
\end{tabular}

Tabel 3 Penambahan jumlah cabang jabon

\begin{tabular}{ccccccccc}
\hline \multirow{2}{*}{ Perlakuan } & \multicolumn{1}{c}{ Pertambahan cabang pada Minggu } \\
\cline { 2 - 9 } & 1 & 2 & 3 & 4 & 5 & 6 & 7 & 8 \\
\hline A0 & 0 & 0 & 1 & 1 & 1 & 1 & 1 & 1 \\
A1 & 0 & 0 & 0 & 0 & 1 & 1 & 1 & 1 \\
A2 & 0 & 0 & 0 & 0 & 1 & 1 & 1 & 1 \\
A3 & 0 & 0 & 0 & 0 & 1 & 1 & 1 & 1 \\
\hline
\end{tabular}

Tabel 4 Hasil pengujian sample tanah pada lahan penelitian

\begin{tabular}{|c|c|c|c|c|}
\hline \multirow[t]{2}{*}{ No. } & \multirow{2}{*}{$\begin{array}{l}\text { Parameter } \\
\text { Pengujian }\end{array}$} & \multicolumn{2}{|c|}{ Sampel } & \multirow[t]{2}{*}{ Kriteria* } \\
\hline & & 1 & 2 & \\
\hline \multirow[t]{3}{*}{1} & $\mathrm{pH}$ & & & \\
\hline & $\mathrm{H}_{2} \mathrm{O}(1: 1)$ & 4.4 & 4.5 & $\mathrm{SM} / \mathrm{M}$ \\
\hline & $\mathrm{CaCl}_{2}(1: 1)$ & 3.7 & 3.8 & SM \\
\hline 2 & C org & 0.59 & 0.52 & SR \\
\hline 3 & N Total & 0.07 & 0.06 & SR \\
\hline 4 & Rasio C/N & 8.4 & 8.7 & $\mathrm{R}$ \\
\hline 5 & $\mathrm{P}_{2} \mathrm{O}_{5}$ & 1.3 & 1.3 & SR \\
\hline 6 & $\mathrm{Ca}(\mathrm{cmol} / \mathrm{kg})$ & 0.34 & 0.40 & SR \\
\hline 7 & $\mathrm{Mg}(\mathrm{cmol} / \mathrm{kg})$ & 0.82 & 1.18 & $\mathrm{R} / \mathrm{S}$ \\
\hline 8 & $\mathrm{~K}(\mathrm{cmol} / \mathrm{kg})$ & 0.17 & 0.16 & $\mathrm{R}$ \\
\hline 9 & $\mathrm{Na}(\mathrm{cmol} / \mathrm{kg})$ & 0.30 & 0.26 & $\mathrm{R}$ \\
\hline 10 & $\mathrm{KTK}(\mathrm{cmol} / \mathrm{kg})$ & 8.01 & 6.04 & $\mathrm{R}$ \\
\hline 11 & $\mathrm{Al}^{3+}(\mathrm{me} / 100 \mathrm{~g})$ & 3.67 & 2.60 & \\
\hline 12 & $\mathrm{H}^{+}(\mathrm{me} / 100 \mathrm{~g})$ & 0.89 & 1.37 & \\
\hline
\end{tabular}

Sampel 1: Lapisan atas tanah, 2: Lapisan bawah tanah Sampel dianalisis di Laboratorium SEAMEO BIOTROP;

*) Kriteria penilaian sifat kimia tanah Pusat Penelitian Tanah (1983) dalam Hardjowigeno (2010); M: Masam; SM: Sangat Masam; R: Rendah; SR: Sangat Rendah 
Penelitian ini merupakan upaya dalam meningkatkan pertumbuhan Jabon pada lahan bekas tambang yang memiliki unsur hara rendah dan keasaman yang tinggi. Jabon merupakan jenis pohon pionir asli Indonesia yang memiliki penyebaran alami yang luas dari Aceh sampai Papua dan tumbuh di tempat-tempat terbuka bekas tebangan atau di kanan-kiri jalan logging. Selain itu, Jabon banyak ditemui di lahan-lahan bekas tambang khususnya di Kalimantan dan tumbuh alami di tempattempat terbuka maupun di sela-sela. Jabon memiliki beberapa kelebihan dibandingkan dengan jenis-jenis pohon kehutanan cepat tumbuh lainnya, diantaranya: 1) Jenis pohon asli Indonesia dengan penyebaran yang luas, 2) mudah diperbanyak, 3) budidaya (produksi bibit, penanaman, dan pemeliharaan) mudah, 4) kayunya dapat digunakan untuk berbagai keperluan (Mansur dan Tuheteru 2010).

Penelitian ini menggunakan pohon jabon yang telah berumur 2.5 tahun namun memiliki pertumbuhan yang tidak terlalu bagus. Hal ini sesuai dengan hasil penelitian Adiwicaksono (2013) menyebutkan bahwa tanah di PT. Tunas Inti Abadi memiliki pH 3.2-3.6 yang rendah sehingga tanah sangat masam. Tanah yang masam dan kesuburan yang rendah diduga menjadi penyebab utama tidak sempurnanya pertumbuhan jabon. Akan tetapi, Safriati (2012) menyebutkan Jabon merupakan tanaman yang dapat bertahan hidup pada tanah yang masam. Berdasarkan pengamatan secara visual di lapang, jabon dapat bertahan hidup namun pertumbuhannya tidak terlalu baik. Sebagian besar pohon jabon yang ditemukan di PT. Tunas Inti Abadi pendek dan gemuk.

Hasil evaluasi tanah menunjukkan kesuburan sampel 1 (lapisan tanah atas setebal $10 \mathrm{~cm}$ ) sedikit lebih rendah daripada sampel 2 (lapisan tanah bawah dari kedalaman $10 \mathrm{~cm}-20 \mathrm{~cm}$ ) terutama pada parameter $\mathrm{pH}$ tanah dan jumlah $\mathrm{Mg}$, hal ini diduga karena terjadi pencucian unsur hara pada tanah lapisan atas oleh air hujan.

Pengapuran bertujuan untuk meningkatkan $\mathrm{pH}$ tanah yang cocok untuk pertumbuhan tanaman. Selain meningkatkan kandungan $\mathrm{Ca}$ dan $\mathrm{Mg}$ tanah, pengapuran bermanfaat bagi tanaman secara tidak langsung. Manfaat tidak langsung pengapuran antara lain meningkatkan ketersediaan $\mathrm{P}$, mengurangi keracunan unsur $\mathrm{Fe}, \mathrm{Al}$ dan $\mathrm{Mn}$; memacu kegiatan jasad renik yang terlibat dalam reaksi-reaksi penting di dalam tanah, memperbaiki struktur tanah, dan mengendalikan penyakit tanaman yang disebabkan oleh patogen terbawa tanah (soil-borne pathogens) (Munawar 2011). Bahan kapur yang digunakan dalam penelitian ini adalah kalsit $\left(\mathrm{CaCO}_{3}\right)$.

Wicaksono (2014) menyebutkan bahwa kapur $\left(\mathrm{CaCo}_{3}\right)$ memberikan pengaruh nyata terhadap pertumbuhan jabon yang tumbuh pada lahan bekas tambang terutama pada faktor diameter. Namun, dalam penelitian ini menunjukkan perbedaan yang nyata terhadap parameter tinggi dan diameter. Hal ini disebabkan karena lokasi penelitian yang tidak sama, umur tanaman jabon yang juga berbeda jauh, dan intensitas cahaya yang lebih kecil. Menurut Gardner et al (1985) penyinaran yang kuat akan menurunkan hormon auksin dan mengurangi tinggi tanaman. Ruas batang tanaman yang ternaungi, seperti pada tegakan yang rapat akan memiliki tinggi yang lebih panjang.

Berdasarkan hasil analisis tanah, Mg menunjukkan jumlah yang lebih besar daripada $\mathrm{Ca}$ sedangkan tanaman membutuhkan komposisi $\mathrm{Ca}$ lebih besar daripada $\mathrm{Mg}$ untuk dapat tumbuh dan tidak stagnan. Kalsit memiliki $40 \% \mathrm{Ca}$ dan tidak mengandung $\mathrm{Mg}$ sehingga dapat meningkatkan nilai $\mathrm{Ca}$ dalam tanah (Munawar 2011). Banyaknya rumput-rumputan yang hanya tumbuh lebat pada tanah yang dilakukan pengapuran menjadikan indikator bahwa pengapuran menjadikan tanah lebih layak dan lebih mendukung pertumbuhan tanaman.

Selain pengapuran, penelitian ini juga ada perlakuan Lubang Resapan Biopori (LRB). Lubang Resapan Biopori atau yang biasa disingkat LRB adalah lubang silindris yang dibuat secara vertikal ke dalam tanah dengan diameter 10-30 cm, kedalaman sekitar $100 \mathrm{~cm}$ atau tidak melebihi kedalaman muka air tanah. Lubang kemudian diisi sampah organik untuk mendorong terbentuknya biopori. Biopori adalah pori berbentuk liang (terowongan keci) yang dibentuk oleh aktivitas fauna tanah atau akar tanaman (Brata dan purwakusuma 2008).

Mulyadi (2008) menyatakan bahwa teknik LRB ini dikembangkan atas dasar prinsip ekohidrologis, yaitu dengan memperbaiki kondisi ekosistem tanah untuk perbaikan fungsi hidrologis ekosistem tersebut. Pemanfaatan sampah organik ke dalam lubang yang kecil dan dalam, ternyata dapat menciptakan habitat yang baik bagi beraneka ragam organisme tanah, khususnya cacing tanah.

Pertumbuhan adalah pertambahan ukuran baik pertambahan jumlah sel, volume dan bobot. Seluruh ciri pertumbuhan dapat diukur, cara pengukuran yang biasa digunakan adalah pengukuran volume atau massa (Salisbury dan Ross 1995). Pengukuran yang digunakan dalam penelitian ini adalah pengukuran pertambahan volume dengan cara mengukur tinggi dan diameter tanaman. Pertumbuhan tanaman dipengaruhi oleh faktor genetik dan faktor lingkungan. (Sitompul dan Guritno 1995). Terdapat 3 jenis serasah yang dimasukkan dalam LRB yaitu tumbuhan LCC, daun akasia, dan sampah dapur. Berdasarkan hasil penelitian, ketiga serasah tersebut memberikan pengaruh yang berbeda-beda terhadap 4 parameter yang diamati. Pada parameter diameter, jenis-jenis serasah dalam LRB memberikan pengaruh yang nyata. Hal ini dibuktikan dalam analisis data yang dilakukan. Berdasarkan uji lanjut, diameter pohon dengan LRB yang berisi LCC memberikan perbedaan yang nyata terhadap pohon kontrol dan pohon dengan LRB berisi daun akasia namun tidak nyata terhadap pohon dengan LRB berisi sampah dapur. Sedangkan pohon dengan LRB berisi daun akasia tidak berbeda nyata dengan pohon kontrol dan pohon dengan LRB berisi sampah dapur.

Parameter tinggi memberikan hasil pengaruh yang berbeda dengan parameter diameter walaupun samasama memberikan pengaruh yang nyata. Pada parameter tinggi, pohon jabon dengan LRB berisi sampah dapur hanya berbeda nyata dengan pohon kontrol yang tidak memiliki LRB. Hal ini menunjukkan ketiga jenis 
serasah dalam LRB tidak memberikan pengaruh yang nyata terhadap parameter tinggi.

Pertumbuhan jumlah daun dan jumlah cabang tidak memiliki pengaruh yang nyata. Hal ini karena tidak terlalu banyak daun dan cabang yang bertambah selama pengukuran dan pengamatan selama 8 minggu. Pertumbuhan jumlah cabang dan daun yang tidak terlalu bagus ini dikarenakan adanya cabang yang patah baik disengaja maupun tidak disengaja oleh manusia.

Hasil penelitian ini menunjukkan bahwa pertumbuhan diameter dan pertumbuhan tinggi Jabon dengan jenis serasah pengisi LRB yang terbaik dan dapat diterapkan pada PT Tunas Inti Abadi adalah LRB berisi daun LCC dan LRB berisi sampah dapur. Kedua jenis ini tidak memiliki perbedaan yang nyata terhadap semua parameter.

\section{SIMPULAN DAN SARAN}

\section{Simpulan}

Berdasarkan penelitian yang telah dilakukan, LRB dapat meningkatkan pertumbuhan diameter dan tinggi jabon pada lahan bekas tambang batubara dan kondisi tanah yang marjinal. Jenis serasah dalam LRB memberikan pengaruh yang nyata terhadap parameter tinggi dan diameter, namun tidak memberikan pengaruh yang nyata terhadap parameter jumlah daun dan jumlah cabang. Daun LCC dan sampah dapur merupakan bahan pengisi LRB yang baik dan tersedia di lokasi PT. Tunas Inti Abadi.

\section{Saran}

Dari penelitian yang telah dilakukan, beberapa saran yang diajukan oleh penulis yaitu perlu diteliti dosis yang tepat untuk daun LCC atau sampah dapur sebagai serasah pengisi LRB agar pertumbuhan jabon lebih maksimal. Perlunya diketahui berapa kali dalam setahun pohon-pohon jabon tersebut dilakukan pengapuran kembali agar tanah tidak terlalu masam. Pemupukan lanjutan seperti NPK juga diperlukan sebagai pendukung dalam meningkatkan unsur hara selain LRB.

\section{DAFTAR PUSTAKA}

Adiwicaksono R. 2013. Pertumbuhan Jabon Merah, Jabon, Dan Sengon Buto Di Lahan Bekas Tambang Batubara PT. Tunas Inti Abadi,
Kalimantan Selatan[ Skripsi]. Bogor (ID): Fakultas Kehutanan, Institut Pertanian Bogor.

Brata RK dan Purwakusuma W. 2008. Teknologi peresapan air tepat guna untuk perbaikan kualitas lingkungan perkotaan. Bogor

[ESDM] Kementerian Energi dan Sumberdaya Mineral. 2013. Surat Keputusan No.2901 K130/MEM/2013 Tentang Perkiraan Kebutuhan dan Presentase Minimal Penjualan Batubara Untuk Kepentingan Dalam Negeri tahun 2014. Jakarta (ID): ESDM

Gardner FP, Pearce RB, Mitchell RL. 1985. Fisiologi Tanaman Budidaya. Susilo H, penerjemah. Jakarta (ID): UI Press. Terjemahan dari: Physiology of Crop Plants

Hardjowigeno S. 2010. Ilmu Tanah. Jakarta (ID): Akademika Presindo

Kementerian Kehutanan. 2009. Peraturan Menteri Kehutanan Republik Indonesia Nomor : $\mathrm{P}$. 60/Menhut-II/2009 tentang Pedoman Penilaian Keberhasilan Reklamasi Hutan. Jakarta: Kementerian Kehutanan.

Mansur I, Tuheteru FD. 2010. Kayu Jabon. Jakarta (ID): Penebar Swadaya.

Martawijaya A, Kartasudjana I, Mandang YI, Prawira SA, Kadir K. 1989. Atlas kayu Indonesia JIlid II. Bogor (ID): Litbanghut.

Mulyadi I. 2008. Analisis efektivitas lubang resapan biopori. [Internet]. [diunduh 20 September 2013]. Tersedia pada http://www.tarumanegara.ac.id

Munawar A. 2011. Kesuburan Tanah dan Nutrisi Tanaman. Bogor (ID): IPB Press

[PT TIA] PT Tunas Inti Abadi. 2010. Laporan Rencana Penutupan Tambang PT Tunas Inti Abadi Kabupaten Tanah Bumbu Kalimantan Selatan. Banjarmasin (ID): PT Tunas Inti Abadi

[RI] Republik Indonesia. 1999. Undang-undang Nomor 41 Tahun 2009. Jakarta (ID): RI

[RI] Republik Indonesia. 2009. Undang-undang Nomor 4 Tahun 2009. Jakarta (ID): RI

Safriati. 2012. Respon pertumbuhan jabon terhadap sumber benih dan dosis pupuk yang berbeda pada daerah bekas tambang batubara di PT Kaltim Prima Coal, Sangatta, Kalimantan Timur [skripsi]. Bogor (ID): Institut Pertanian Bogor.

Salisbury FB, Ross CW. 1995. Fisiologi Tumbuhan Jilid 3. Bandung (ID): Penerbit ITB Bandung.

Sitompul SM, Guritno B. 1995. Analisis Pertumbuhan Tanaman. Yogyakarta (ID): Gadjah Mada University Press. 